\title{
PERUBAHAN TUTUPAN TERUMBU KARANG DITINJAU DARI BANYAKNYA WISATAWAN DI TANJUNG GELAM KEPULAUAN KARIMUNJAWA MENGGUNAKAN CITRA SATELIT LANDSAT 8 OLI
}

\author{
Coral Reef Changes Based on the Number of Tourism in Tanjung Gelam Karimunjawa Islands \\ Using Satellite Images Landsat 8 OLI
}

Moch Farid, Pujiono Wahyu P*), dan Supriharyono

Program Studi Manajemen Sumberdaya Perairan, Departemen Sumberdaya Akuatik

Fakultas Perikanan dan Ilmu Kelautan Universitas Diponegoro

Jl. Prof. Soedarto, SH, Tembalang, Semarang, Jawa Tengah - 50275, Telp/Fax. +6224 7474698

Email : fariedmoch@gmail.com

\begin{abstract}
ABSTRAK
Terumbu karang merupakan salah satu sumberdaya pesisir dan lautan yang mempunyai produktifitas dan keanekaragaman hayati yang tinggi. Keberadaan terumbu karang banyak memberikan pengaruh pada masyarakat Karimunjawa, sebagai panorama alam yang menarik untuk kegiatan wisata. Penelitian ini bertujuan untuk mengetahui tingkat perkembangan wisata, tingkat sensitifitas dan kondisi terumbu karang serta perubahan luasanya di kawasan Tanjung Gelam. Penelitian dilaksanakan pada bulan Agustus 2017 bertempat di kawasan pemanfaatan bahari Tanjung Gelam, Kepulauan Karimunjawa Jepara. Metode pengukuran sensitifitas mengacu pada pengukuran kerentanan ekosistem terumbu karang parameter pengamatan yang diambil yaitu kondisi tutupan karang hidup, kerapatan terumbu karang, kelimpahan ikan, tipe pertumbuhan terumbu karang, status perlindungan, spesies yang dilindungi, dan kelandaian. Kuesisoner digunakan untuk mengetahu respon dan prilaku wisatawan pada kawasan tanjung gelam dengan jumlah responden yang diambil yaitu 25 wisatawan, 10 pedagang dan 10 operator wisata. Pengolaan citra satelit menggunakan transformasi Lyzenga. Hasil penelitian menunjukkan perkembangan wisata di Kepulauan karimunjawa dari tahun 2014-2016 mencapai kenaikan sebanyak 39.178 orang, sedangkan tingkat sensitifitas ekosisitem terumbu karang di kawasan tanjung gelam berada pada kategori rendah dengan nilai 2,14, dengan kondisi tutpan karang hidup pada kriteria rusak buruk dengan nilai rata rata 10,28\% dan perubahan luasan tutupan terumbukarang di Tanjung Gelam didapatkan perubahan luasan habitat terumbu karang yang berkurang sebesar 4,22 Ha dari tahun 2015-2017.
\end{abstract}

Kata Kunci: Terumbu karang, Sensitifitas, transformasi Lyzenga. Karimunjawa

\section{ABSTRACT}

Coral reefs are one of the coastal and ocean resources that have high productivity and biodiversity. The existence of coral reefs give much influence to the people of Karimunjawa, as an interesting natural panorama for tourism activities. This research aims to determine the level of tourism development, the level of sensitivity and condition of coral reefs and changes in the area of Tanjung Gelam. The research was conducted in August 2017 located in Tanjung Gelam marine utilization area, Karimunjawa island of Jepara. Methods of measurement of sensitivity include the measurement of living coral cover conditions, coral reef density, fish abundance, coral growth type, protection status, protected species, and cleverness. Questionnaires are used to find out the responses and behavior of tourists in the region of Tanjung Pinam with the number of respondents taken are 25 tourists, 10 merchants and 10 tour operators. Satellite image managers use the Lyzenga transformation. The results showed that the development of tourism in Karimunjawa Islands from 2014-2016 reached as much as 39,178 people, while the level of coral reef ecosystem sensitivity in the region of Tanjung Pinang was in the low category with a value of 2.14, with the living coral study on badly damaged criteria with value the average of 10.28 and the change of cover area in Tanjung Gelam found a change in coral reef habitat area which decreased by 4.22 Ha from 2015 2017 year.

Keywords: Coral Reef; Sensitivity; Lyzenga Transformation; Karimunjawa

\section{PENDAHULUAN}

Terumbu karang merupakan salah satu sumberdaya pesisir dan lautan yang mempunyai produktifitas organik dan keanekaragaman hayati yang tinggi. Kondisi terumbu karang banyak memberikan pengaruh pada wilayah pesisir. Selain itu terumbu karang juga mempunyai fungsi ekologis dan ekonomi antara lain sebagai pelindung terhadap terjadinya erosi, sebagai tempat penyedia nutrien bagi biota perairan, tempat berlindung, tempat pemijahan, tempat bermain dan asuhan bagi berbagai biota karang, serta sebagai supporting system bagi masyarakat pesisir yang bermata pencaharian sebagai nelayan dan pelaku wisata bahari (Dahuri, 2003). 
Kepulauan Karimunjawa merupakan gugusan pulau di laut Jawa dengan keanekaragaman sumberdaya hayati yang berlimpah, memiliki berbagai jenis ekosistem seperti hutan hujan tropis rendah, hutan pantai, hutan mangrove, ekosisitem lamun, dan ekosisitem terumbu karang (BTNKJ, 2004). Kepulauan Karimunjawa terletak di Kabupaten Jepara Provinsi Jawa Tengah, berdasarkan Surat Keputusan Mentri Kehutanan dan Perkebunan No. 78/kpts-II/1999 Kepulauan Karimunjawa di tetapkan menjadi taman nasional. Menurut keputusan direktur jendral perlindungan hutan dan konservasi alam No: SK.28/IV-SET/2012 Kepulauan Karimunjawa terbagi menjadi 9 (sembilan) zona pemanfaatan dan perlindungan behari dengan salah satu zona yang di miliki yaitu zona inti .Dengan adanya zona pemanfaatan bahari sebagai wisata bahari di Kepulauan Karimunjawa menimbulkan kehawatiran yang cukup tinggi terhadap kelestarian ekositem disekitar kawasan tersebut.

Hingga tahun 2016 telah tercatat kunjungan wiasatawan ke Kepulauan Karimunjawa yaitu pada tahun 2014 sebanyak 8.669 wisatawan macanegara dan 70.454 wisatawan nusantara, 2015 sebanyak 7.579 wisatawan mancanegara dan 84.536 wisatawan nusantara, dan 2016 sebanyak 7.317 wisatawan mancanegara dan 110.984 wisatawan nusantara (BPS,2014; BPS,2015; BPS,2016). Peningkatan jumlah wisatawan tersebut menimbulkan kehawatiran mengenai keberlangsungan kegiatan wisata yang tidak terkendali bagi keberlanjutan daerah wisata maupun ekologi yang ada apabila tidak di tangani secara serius (BTNKJ,2012). Dalam hal ini terumbu karang merupakan salah satu ekosistem laut yang paling terancam sebagai akibat dari gangguan perubahan alam, maupun dari antropogenik, baik yang berskala global maupun lokal (Lasagna et.al, 2014).

Tujuan dalam penelitian ini adalah:

1. Mengetahui pengaruh pariwisata terhadap terumbu karang di Tanjung Gelam.

2. Mengetahui tingkat sensitifitas (sensitivity) dan kondisi terumbu karang pada zona pemanfaatan bahari (Tanjung gelam).

3. Mengetahui perubahan tutupan terumbu karang di Tanjung gelam kepulauan Karimunjawa menggunakan citra satelit.

\section{MATERI DAN METODE \\ Materi}

Materi yang digunakan pada penelitian ini adalah terumbu karang di zona pemanfaatan bahari Tanjung Gelam Kepulauan Karimunjawa dan data Citra Satelit landsat 8 OLI tahun 2015-2017 dari zona pemanfaatan bahari Tanjung Gelam Kepulauan Karimunjawa, terdiri dari beberapa alat dan bahan.

Alat yang digunakan meliputi alat untuk sampling lapangan dan pengolahan data. Alat yang digunakan pada sampling lapangan adalah rol meter, alat snorkel, water quality checker (WQC), papan data, kamera underwater, GPS, buku identifikasi karang. Alat yang digunakan untuk pengolahan data adalah Notebook Intel core i3 (1,8 GHz) 2 GB RAM, Hardisk Eksternal 100GB, software Er Mapper 7.0, software Microsoft Excel 2010, dan software Microsoft Word 2010. Bahan yang digunakan terdiri dari citra Landsat 8 tahun 2015, tahun 2016 dan tahun 2017, peta rupa bumi Indonesia, serta pengamatan habitat terumbu karang secara langsung.

\section{Metode}

Metode penelitian yang digunakan dalam penelitian ini adalah eksploratif. Penelitian eksploratif dilakukan dengan mencari informasi untuk memberikan gambaran yang berkaitan dengan materi penelitian. Teknik Penelitian yang digunakan dalam penelitian ini meliputi teknik purpousive sampling untuk pengumpulan data respon wisatawan, teknik pengumpulan data karang, analisa data karang, analisa kualitas perairan dan teknik pengolahan data citra. Pengamatan ekosistem di lapangan digunakan untuk membantu proses interpretasi citra. Penelitian mengenai teknik pengumpulan data karang dilakukan dengan menggunakan metode Line Transect.

\section{Pengambilan Data Lapangan}

Pengambilan data lapangan dilakukan pada 3 stasiun di zona pemanfaatan bahari yaitu Tanjung Gelam di Kepulauan Karimunjawa terletak di sebelah Timur Laut kota Semarang tepatnya pada posisi 50 40' - 50 57' LS dan 1100 4' - 1100 40' BT (Gambar 1). Untuk mengamati potensi kontak fisik wisatawan dari kegiatan selam dan snorkling beberapa prilakau mengancam yang perlu diperhatikan pada Tabel 1.

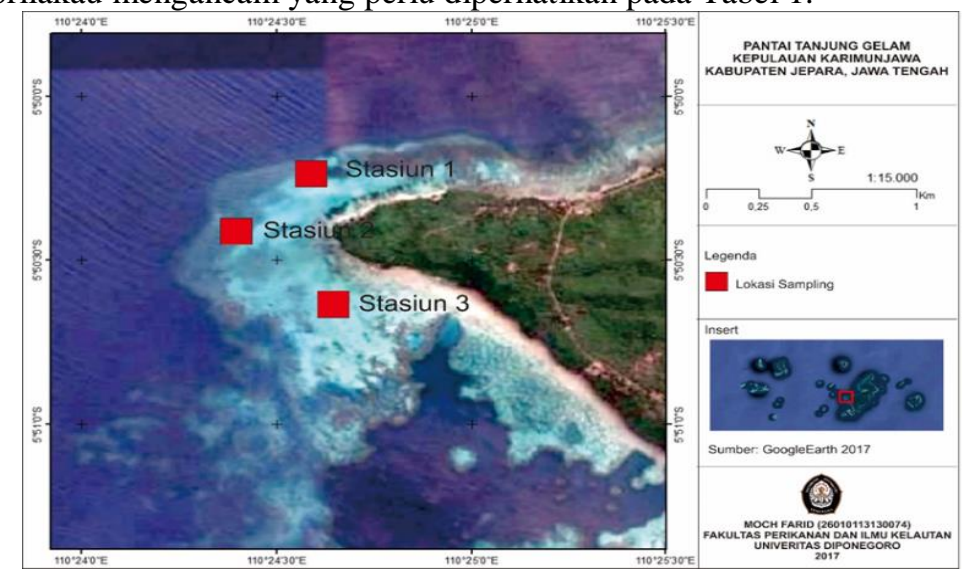

Gambar 1. Lokasi Pengambilan Data

\footnotetext{
${ }^{\circledR}$ Copyright by Management of Aquatic Resources (MAQUARES)
} 
Tabel 1. Potensi Kontak Fisik Wisatawan Terhadap Terumbu Karang

\begin{tabular}{lll}
\hline No & Perilaku yang mengancam & Keterangan \\
\hline 1 & Fins kick & Fins yang terkena karang \\
2 & Seet, stand, kneel & Duduk, berdiri, berlutut pada karang \\
3 & siltting & $\begin{array}{l}\text { Membuat sedimen teraduk yang berpotensi menutup } \\
\text { karang }\end{array}$ \\
& & Menyentuh karang \\
4 & Hand touch & Mengambil biota \\
5 & Pick up marien live & Mengganggu biota \\
6 & Harass mariene life & Memungut dan mengkoleksi benda -benda atau \\
7 & Collect objects or animals & hewan \\
& & Bagian tubuh yang tidak sengaja terkena karang
\end{tabular}

Sumber : Webler and Jakubowski, (2016)

Berikut adalah rumus untuk kerusakan individu dalam satukali trip :

$$
\text { Di.pm } \left.=\left(\left(\sum N r\right) / N o\right) /(T t)\right)
$$

Keterangan :

Di.pm : Kerusakan individu per menit $\quad$ No : Jumlah wisatawan per trip

$\mathrm{Tt} \quad$ : Waktu yang disediakan operator wisata $\quad \mathrm{Nr} \quad$ : Prilaku yang mengancam

Pengamatan parameter kepekaan (sensitivity) mengacu pada Suhery et al., (2017) menggunakan persamaan berikut:

$$
S=\frac{G T+S L+P E+P C+C D+P S+F A}{7}
$$

Keterangan :

$\begin{array}{llll}\text { GT } & =\text { Tipe pertumbuhan } & \text { CD } & =\text { Kerapatan } \\ \text { SL } & =\text { Kelandaian } & \text { PS } & =\text { Spesies dilindungi } \\ \text { PE } & =\text { Status perlindungan } & \text { FA } & =\text { Kelimpahan ikan } \\ \text { PC } & =\text { Persentase tutupan } & & \end{array}$

Dengan pembagian kategori sebagai berikut :

Tabel 2. Kategori Kepekaan (Sensitivity).

\begin{tabular}{ll}
\hline Kategori & Sensitivity \\
\hline Sangat Rendah & 1 \\
Rendah & 2 \\
\hline Sedang & 3 \\
Tinggi & 4 \\
Sangat Tinggi & 5 \\
\hline
\end{tabular}

Mengacu pada English et al (1994) dan Keputusan Kepala Badan Pengendalian Dampak Lingkungan No.47 Tahun 2001 tentang Pedoman Pengukuran Kondisi Terumbu Karang, maka untuk mengetahui kondisi terumbu karang dilakukan survey dengan menggunakan metode Lifeform transek garis. Pengambilan data dilakukan pada 3 stasiun dengan dua titik pada setiap stasiuanya, panjang line menggunakan $50 \mathrm{~m}$ sejajar dengan garis pantai dengan jarak $100 \mathrm{~m}$ dari pantai dan setiap titik pada stasiun berjarak $5 \mathrm{~m}$.

Untuk mengetahui sebaran karang atau struktur komunitas karang perlu dilakukan pengolahan data, analisa yang dilakukan dapat dihitung dengan rumus sebagai berikut:

a. Persentase penutupan karang (UNEP, 1993)

$$
N i=\frac{L i}{L} \times 100 \%
$$

Keterangan:

$\mathrm{Ni} \quad=$ persentase penutupan koloni karang

$\mathrm{Li} \quad=$ panjang koloni karang perpanjangan transek garis $(\mathrm{cm})$

$\mathrm{L} \quad=$ panjang garis transek $(50 \mathrm{~m})$

b. Kelimpahan Ikan

Kelimpahan adalah banyaknya jumlah individu dan jumlah jenis yang ditemukan pada luas daerah pengamatan. Kelimpahan ikan karang dapat dihitung dengan menggunakan rumus (Odum, 1979). 
Keterangan :

$$
D=\frac{10000 \times \sum N i}{A}
$$

$\mathrm{D} \quad=$ Kepadatan / kelimpahan (Ind/ha)

A $=$ Luas pengambilan data $(\mathrm{m} 2)$

$\mathrm{Ni} \quad=$ Jumlah Individu (Ind)

$10.000=$ Konversi dari $\mathrm{m} 2 \mathrm{ke}$ ha

c. Keterkaitan Jumlah Wisata dengan Perubahan Luasan Terumbu Karang

Penelitian ini menggunakan teknik analisis regresi linier sederhana, karena variabel yang terlibat dalam penelitian ini ada dua, yaitu perkembangan jumlah wisatawan sebagai variabel bebas dan dilambangkan dengan $\mathrm{X}$ serta perubahan luasan terumbu karang sebagai variabel terikat dan dilambangkan dengan Y berpangkat satu. Menurut Agus (2007) Analisi regresi linier sederhana dapat dilaksanakan apabila telah memenuhi syarat-syarat sebagai berikut:

1. Sampel diambil secara random (acak)

2. Variabel X dan variabel Y mempunyai hubungan yang kausal, dimana X merupakan sebab dan Y merupakan akibat.

3. Nilai Y mempunyai penyebaran yang berdistribusi normal.

4. Persamaan tersebut hendaknya benar-benar linier.

Menurut Razak (1991) dalam Mutaqin et al., 2014) nilai keeratan pada regresi linier dikategorikan :
$0,00-0,20$
= hubungan sangat lemah
$0,71-0,90$
= hubungan kuat
$0,21-0,40$
$=$ hubungan lemah
$0,91-1,00$
= hubungan sangat kuat
$0,41-0,70$
= hubungan sedang

Koefisien korelasi (R) dipakai hanya untuk menyatakan keeratan hubungan yang bersifat linier sederhana. Koefisien determinasi (Adjusted R2) mencerminkan seberapa besar variabel dependen dapat diterangkan oleh variabel independen (Mutaqin et al., 2014).

\section{Teknik Pengolahan Data Citra}

Pengolahan citra Landsat dilakukan secara digital meggunakan perangkat lunak ER Mapper 7.0 melalui beberapa tahapan pemrosesan citra, yaitu :
a. Pengambilan data Landsat
d. Koreksi radiometrik
b. Penggabungan band
e. Transformasi Lyzenga
c. Koreksi geometrik
f. Klasifikasi citra tak terawasi (Unsupervissed)

Menurut Damayanti (2012), uji akurasi dilakukan terhadap kelompok piksel yang mewakili objek tertentu yang diambil sebagai sampel dalam suatu poligon objek dengan kooordinat lokasi yang sama di lapangan. Selanjutnya sampel yang telah diambil dari lapangan dibandingkan dengan piksel hasil klasifikasi. Metode ini dikenal dengan error matrix atau confution matrix.

\section{HASIL DAN PEMBAHASAN}

Hasil

\section{Potensi Kontak Fisik Wisatawan Terhadap Terumbukarang}

Berdasarkan pengamatan di lapangan dari beberapa prilaku wisatawan yang berpotensi merusak (kontak langsung). Yaitu diantaranya fins kick (Fins yang terkena karang), siltting (Membuat sedimen teraduk yang berpotensi menutup karang), hand tauch (Menyentuh karang), dan body brush (Bagian tubuh yang tidak sengaja terkena karang), dari hasil pengamatan didapat nilai perusakan individu permenit yaitu 0,33. Adapun jumlah perkembangan wisatawan pada setiap tahunya tersaji pada Tabel 3.

Tabel 3. Hasil Data Pariwisata

\begin{tabular}{cccccccc}
\hline \multirow{2}{*}{ TAHUN } & \multicolumn{4}{c}{ Bulan } & \multicolumn{2}{c}{ Jumlah } & \multirow{2}{*}{ Total } \\
\cline { 2 - 6 } & \multicolumn{2}{c}{ Jan-Jun } & \multicolumn{2}{c}{ Jul-Des } & \multicolumn{2}{c}{} \\
\cline { 2 - 7 } & Wisman & Wisnus & Wisman & Wisnus & Wisman & Wisnus & \\
\hline $\mathbf{2 0 1 4}$ & 820 & 19,155 & 7,849 & 51,299 & 8,669 & 70,454 & 79,123 \\
$\mathbf{2 0 1 5}$ & 3419 & 30,129 & 4,160 & 54,407 & 7,579 & 84,536 & 92,115 \\
$\mathbf{2 0 1 6}$ & 2147 & 60,411 & 5,170 & 50,573 & 7,317 & 110,984 & 118,301 \\
\hline
\end{tabular}

Sumber:BPS Jepara

Data pariwisata ke Pulau Karimunjawa didominasi oleh (wisnus) wisatawan nusantara atau wisatawan lokal yang mencapai kisaran $90 \%$ dan $10 \%$ sisanya yaitu (wisman) wisatawan mancanegara.

\section{Pengukuran Ekosistem Terumbu Karang}

Hasil pengamatan pada parameter fisika dan kimia di perairan Tanjung Gelam Taman Nasional Karimunjawa tersaji pada tabel 4. 
Tabel 4. Hasil Pengukuran Parameter Fisika dan Kimia Perairan

\begin{tabular}{ccccccc}
\hline Stasiun & Titik & \multicolumn{5}{c}{ Parameter } \\
\cline { 3 - 7 } & & Suhu (c) & $\begin{array}{c}\text { Kedalaman } \\
(\mathrm{m})\end{array}$ & Kecerahan $(\mathrm{m})$ & $\begin{array}{c}\text { Salinitas } \\
(\mathrm{ppt})\end{array}$ & $\mathrm{pH}$ \\
\hline 1 & 1 & 28 & 2 & 2 & 34,7 & 8,16 \\
& 2 & 28 & 2,5 & 2,5 & 34,5 & 8,15 \\
2 & 1 & 28 & 0,5 & 0,5 & 34,9 & 8,10 \\
& 2 & 29 & 1,7 & 1,7 & 34,7 & 8,07 \\
3 & 1 & 29 & 1,5 & 1,5 & 34,8 & 8,19 \\
& 2 & 29 & 2,9 & 2,9 & 34,6 & 8,15 \\
\hline
\end{tabular}

Berdasarkan perhitungan penutupan karang didapatkan hasil berupa persentase penutupan karang di Tanjung Gelam Taman Nasional Karimunjawa. Adapun data tersebut tersaji pada tabel dibawah ini: Tabel 5. Hasil Pengukuran Persentase Penutupan Karang di Tanjung Gelam

\begin{tabular}{ccccccc}
\hline \multirow{2}{*}{ Stasiun } & Titik & \multicolumn{5}{c}{ Kategori Lifeform } \\
\cline { 3 - 6 } & & Coral life (\%) & $\begin{array}{c}\text { Dead coral } \\
(\%)\end{array}$ & $\begin{array}{c}\text { Other life } \\
(\%)\end{array}$ & $\begin{array}{c}\text { Abiotic } \\
(\%)\end{array}$ & Total (\%) \\
\hline \multirow{2}{*}{1} & 1 & 2,30 & 30,90 & 12,70 & 54,10 & 100 \\
& 2 & 11,74 & 13,86 & 10,14 & 64,26 & 100 \\
& 1 & 9,14 & 57,36 & 7,50 & 26 & 100 \\
3 & 2 & 29,70 & 51,10 & 0,80 & 18,40 & 100 \\
& 1 & 3,90 & 91,60 & 1,60 & 2,90 & 100 \\
& 2 & 4,90 & 92,10 & 1,40 & 1,60 & 100 \\
\hline \multicolumn{2}{c}{ Rata - Rata } & 10,28 & 56,15 & 5,69 & 27,88 & 100 \\
\hline
\end{tabular}
berikut :

Tingkat kerentanan kawasan Tanjung Gelam berdasarkan parameter sensitifitas ( sesitivity )sebagai

Tabel 6. Hasil Parameter Sensitifitas ( sensitivity ) Karang di Tanjung Gelam

\begin{tabular}{llcc}
\hline No & Parameter sensifitas (sensivity) & Hasil pengamatan & skor \\
\hline 1. & Tipe pertumbuhan terumbu karang & Fringing reef & 3 \\
2. & Kelandaian & landai & 4 \\
3. & Status perlindungan ekosisitem & Zona pemanfaatan bahari & 3 \\
4. & Persentase tutupan karang & $10.28 \%$ & 1 \\
5. & Kerapatan karang & $0.32 \mathrm{koloni}$ & 2 \\
6. & Spesies yang di lindungi & Tidak ada & 1 \\
7. & Kelimpahan ikan & 920 ind/Ha & 2 \\
\hline Nilai sensitifitas & & 2,29 \\
\hline \multicolumn{2}{l}{ Kategori sensitifitas (sensitivity) } \\
\hline
\end{tabular}

Keterkaitan anatara perkembangan jumlah wisatawan dengan kerusakan terumbu karang di Tanjung Gelam berdasarkan regresi linier sederhana sebagai berikut :

Tabel 7. Kesimpulan Model Analisis Regresi Linier Sederhana

\begin{tabular}{ccccc} 
Model & $\mathrm{R}$ & $\mathrm{R}^{2}$ & Adjusted $\mathrm{R}^{2}$ & Std. Error of the Estimate \\
\hline 1 & 0,984 & 0,698 & 0,935 & 4,538
\end{tabular}

Berdasarkan Tabel 8 diperoleh koefisien korelasi (R) sebesar 0,984 yang berarti kaitan kenaikan jumlah dengan penutupan terumbu karang dikategorikan berkaitan sangat kuat. Nilai koefisien determinasi (Adjusted R2) sebesar 0,935 nilai ini menunjukkan sebesar 93,5\% penutupan terumbu karang dipengaruhi oleh jumlah wisatawan sisanya sebesar $6,5 \%$ dipengaruhi oleh faktor lain, seperti suhu dan pasang surut.

\section{Pengolahan Citra}

Uji akurasi digunakan sebagai fiksasi hasil interpretasi citra dengan data di lapangan. Adapun matriks uji akurasi (confusion matriks) untuk uji akurasi hasil citra di kawasan Tanjung Gelam tersaji pada tabel 8.

Dalam penelitian ini didapatkan nilai uji akurasi sebesar $75 \%$. Merujuk dari hal ini uji akurasi yang didapatkan bisa dikatakan juga cukup memadai walaupun hanya menggunakan citra satelit Landsat 8 . Selain itu hasil interpretasi terumbu karang memiliki nilai kebenaran 5 banding 6, artinya informasi tutupan terumbu karang yang diberikan oleh citra Landsat menggunakan algoritma Lyzenga cukup mewakili keadaan di lapangan. Nilai akurasi pemetaan antara $60-80 \%$ dapat direkomendasikan bagi kegiatan inventarisasi untuk pemantauan sumberdaya (Green et al., 2000 dalam Wahidin et al., 2014). 
Hasil pengolahan data citra di Pantai Tanjung Gelam tahun 2015 diklasifikasikan menjadi 6 kategori yaitu karang hidup, karang mati, pecahan karang, padang lamun, pasir, dan lautan. Hasil pengolahan data tersebut dapat dilihat pada Gambar 1 dan 2.

Tabel 8. Hasil Uji Akurasi (confusion matrix) di Tanjung Gelam

\begin{tabular}{|c|c|c|c|c|c|c|c|c|c|}
\hline \multirow{2}{*}{\multicolumn{2}{|c|}{ Confusion Matriks }} & \multicolumn{8}{|c|}{ Data Hasil Lapangan } \\
\hline & & $\begin{array}{l}\text { Karang } \\
\text { Hidup }\end{array}$ & $\begin{array}{l}\text { Karang } \\
\text { Mati }\end{array}$ & $\begin{array}{l}\text { Pecahan } \\
\text { Karang }\end{array}$ & Lamun & Pasir & Laut & Total & Omisi \\
\hline \multirow{9}{*}{ 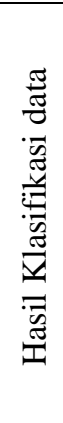 } & Karang Hidup & 5 & 0 & 0 & 0 & 0 & 0 & 5 & 0 \\
\hline & Karang Mati & 1 & 3 & 0 & 0 & 0 & 0 & 4 & 1 \\
\hline & Pecahan Karang & 0 & 1 & 5 & 1 & 1 & 0 & 8 & 3 \\
\hline & Lamun & 0 & 1 & 0 & 3 & 0 & 0 & 4 & 1 \\
\hline & Pasir & 0 & 1 & 1 & 2 & 5 & 0 & 9 & 4 \\
\hline & Laut & 0 & 0 & 0 & 0 & 0 & 6 & 6 & 0 \\
\hline & Total & 6 & 6 & 6 & 6 & 6 & 6 & 36 & \\
\hline & Komisi & 1 & 3 & 1 & 3 & 1 & 0 & & \\
\hline & Total diagonal & 27 & & & & & & & \\
\hline
\end{tabular}
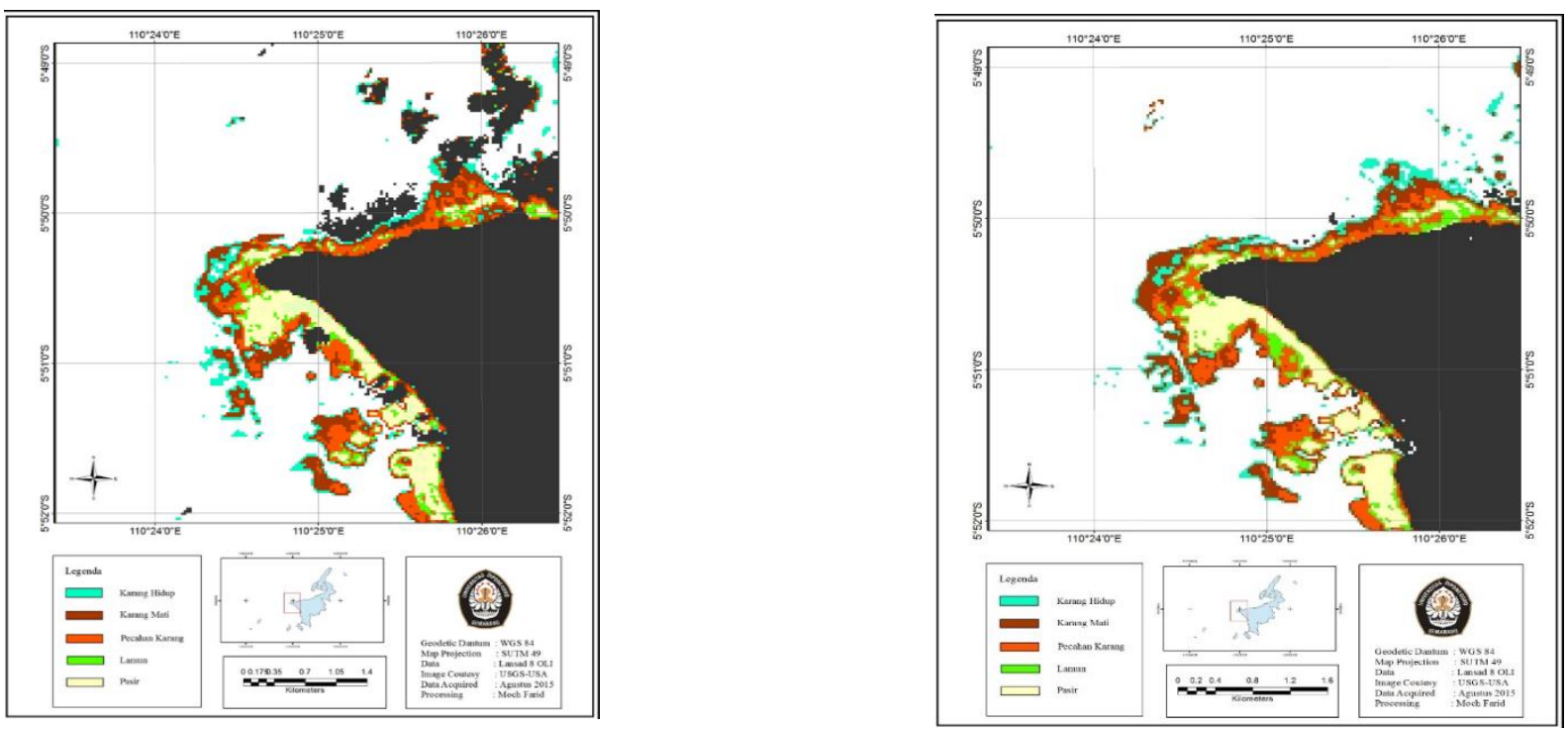

Gambar 1. Peta Tahun 2015

Gambar 2. Peta Tahun 2016

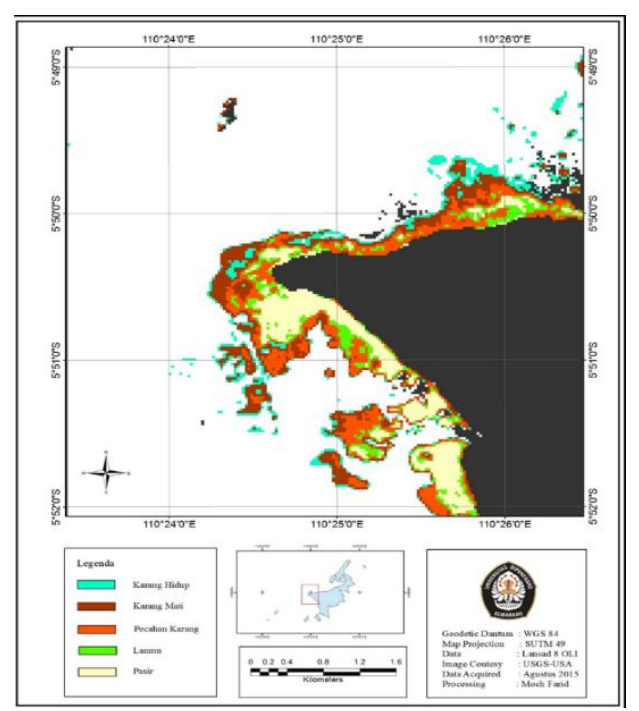

Gambar 3. Peta Tahun 2017

${ }^{\circledR}$ Copyright by Management of Aquatic Resources (MAQUARES) 
Berdasarkan pengolahan data citra yang dilakukan peneliti di data citra Pantai Tanjung Gelam menggunakan data Landsat 8 tahun 2017, 2016 dan 2015 didapatkan perubahan luas terumbu karang sebagai berikut :

Tabel 9. Hasil Citra Satelit Perubahan Luas Terumbu Karang di Tanjung Gelam

\begin{tabular}{lcccccc}
\hline Jenis Tutupan & \multicolumn{2}{c}{ tahun 2015} & \multicolumn{2}{c}{ tahun 2016} & \multicolumn{2}{c}{ tahun 2017} \\
\cline { 2 - 6 } karang Hidup & Ha & $\%$ & Ha & $\%$ & Ha & $\%$ \\
\cline { 2 - 6 } & 73.44 & 2.96 & 61.2 & 2.34 & 69.21 & 2.65 \\
\hline karang mati & 130.41 & 5.25 & 124.47 & 4.76 & 122.13 & 4.67 \\
pecahan karang & 106.29 & 4.28 & 120.78 & 4.62 & 122.31 & 4.68 \\
lamun & 41.22 & 1.66 & 47.43 & 1.81 & 56.07 & 2.15 \\
\hline pasir & 104.31 & 4.20 & 122.31 & 4.68 & 111.78 & 4.28 \\
laut & 2026.17 & 81.64 & 2137.77 & 81.78 & 2131.29 & 81.57 \\
\hline Tottal & 2481.84 & 100.00 & 2613.96 & 100.00 & 2612.79 & 100.00 \\
\hline
\end{tabular}

\section{Pembahasan}

\section{Parameter Fisika dan Kimia Perairan}

Suhu air permukaan pada masing-masing lokasi pengambilan sampel berkisar antara $28,5^{\circ} \mathrm{C}-29,3^{\circ} \mathrm{C}$. Kisaran suhu air yang baik di perairan karang berdasarkan Kepmen Lingkungan Hidup no 51 tahun 2004 tentang Baku Mutu Air Laut adalah antara $28-30^{\circ} \mathrm{C}$. Kriteria suhu air laut untuk wisata bahari adalah suhu alami dan dapat ditolerir bila terjadi perubahan suhu sampai dengan $<2^{\circ} \mathrm{C}$, jadi kisaran suhu permukaan perairan pada kawasan Tanjung Gelam masih pada kisaran yang dapat diterima. Adapun kisaran suhu untuk perkembangan terumbu karang yang optimal terjadi pada perairan dengan rata-rata suhu tahunan $23-25^{\circ} \mathrm{C}$ (Nybakken, 1993).

Nilai kecerahan yang di dapat pada pengukuran setiap setasiun yaitu sampai dasar atau $100 \%$ cahaya dapat masuk hingga dasar perairan. Adapun kedalaman yang didapat pada setiapa lokasi pengambilan sampel yaitu berkisar $0-2,9$ meter. Nilai kecerahan sesuai baku mutu air laut untuk wisata bahari adalah $>6 \mathrm{~m}$, baku mutu air laut untuk menunjang kehidupan karang adalah $>5 \mathrm{~m}$. Cahaya, intensitas cahaya matahari berpengaruh pada proses fotosintesa yang akan di lakukan oleh zooxanthela dapat berjalan. Nilai maksimum penyerapan cahaya pada kolom perairan untuk pertumbuhan karang umumnya terjadi pada 30-40\% irradians dibawah permukaan laut (Munasik, 2009). Berkaitan dengan pengaruh cahaya tersebut maka kedalaman mebatasi kehidupan binatang karang. pada perairan jernih memungkinkan penetrasi cahaya bisa sampai pada lapisan yang sangat dalam. Namun secara umum karang tumbuh baik pada kedalaman kurang dari 20 meter (Supriharyono, 2017).

Nilai salinitas yang terukur pada lokasi pengambilan sampel berkisar antara 34.5-34.9 ppt, dengan baku mutu air laut untuk biota laut adalah antara 33-34 ppt. Kondisi salinitas yang baik bagi pertumbuhan hewan karang menurut Nybakken (1993), berkisar antara 32-35 ppt. Kriteria salinitas air laut untuk wisata bahari adalah salinitas alami dan masih diperbolehkan perubahan sampai dengan $<5 \%$ salinitas rata-rata musiman.

Nilai $\mathrm{pH}$ yang terukur pada lokasi penelitian antara 8.07-8.19 variasi ini masih bisa di katakan aman untuk suatu perairan. Umumnya $\mathrm{pH}$ air laut relatif stabil dengan kisaran antara 7,5-8,4. Pescod dalam Susana (2005) menyatakan kisaran pH yang ideal bagi biota laut nilainya berkisar antara 6,5-8,5. Sedangkan KLH (2004) menetapkan nilai $\mathrm{pH}$ untuk biota laut berkisar antara 7-8,5.

\section{Kondisi Terumbu Karang}

Pengambilan data jenis lifeform menggunakan metode line transec pada 3 stasiun. Pada setiap stasiun dilakaukan pengulanagan dengan 2 titik garis yang berjarak 5 meter. Kedalaman pada setiap titik bervariasi dari 0,6 $\mathrm{m}$ hingga $2.9 \mathrm{~m}$ pada daerah reef flat. Hal ini dilakukan untuk mencari gambaran dampak dari kegiata pariwisata pantai terhadap ekosisitem terumbu karang di kawasan Tanjung Gelam karena pada rentan kedalaman tersebut merupakan kedalaman ideal untuk kegiatan wisata pantai dan kegiatan snorkling. Waktu pengamatan dilakukan dari pagi hingga sore hari dengan kondisi cuaca yanng relatis cerah. Pengamatan di gambarkan dengan penggolongan 4 kategori lifeform . Tabel hasil kategori lifeform tersaji pada (Tabel.5).

Perbandingan tutupan terumbu karang pada stasiun 1-3 (titik 1 -6) pada lokasi sampling yaitu terjadi fluktuasi yang cukup signifikan pada setiap kategori lifeform, pada stasiun 1 (titik 1 dan 2) didominasi oleh kategori abiotik yang berkisar 54.10-64.26\% pada kategori abiotik ini di dominasi oleh lifeform RB (rubble), dan kategori terendah yaitu coral life berkisar 2.30-11.7\%. Pada stasiun 2 (titik 3 dan 4) didominasi oleh dead coral berkisar 51.10-57.36\% dan kategori terendah yaitu other life berkisar 0.80-7.50\%. Pada stasiun 3 (titik 5 dan 6) mempunyai kemiripan dengan stasiun 2 yaitu didominasi oleh dead coral dengan penutupan antara 91.60-92.10\%. Tututpan yang terendah yaitu other life 1.40-1.60\%. Hasil penelitian Sulisyati et., al (2014), pada kawasan Tanjung Gelam didapatkan nilai tutupan Lifeform DCA (dead coral algae) sebesar 55,3\%.

Tutupan pada stasiun 1 nilai penutupan tertinggi yaitu kategori abiotic yang mencapai $64.26 \%$ dan pada stasiun 2 dan 3 persentase tertinggi yaitu kategori dead coral yang mencapai $92.10 \%$, disini terjadi penurunan lifeform dari karang mati menjadi pecahan karang yang cukup besar. Penurunan lifeform diduga akibat lokasi

${ }^{\circledR}$ Copyright by Management of Aquatic Resources (MAQUARES) 
pada stasiun 1 yang merupakan lokasi utama kegiatan pariwisata di kawasan Tanjung Gelam. Selain itu, faktor yang mendorong penurunan persentasi tutupan karang adalah tekanan dari kegiatan pariwisata. Pada beberapa lokasi dengan aktifitas pariwisata tinggi, seperti di Pulau Menjangan Kecil, dijumpai bukti kerusakan karang bercabang yang patah maupun karang massif yang mati akibat terinjak oleh wisatawan (Pardede et al., 2016).

Pada stasiun 2 dan 3 kategori tuupan tertinggi yaitu dead coral mencapai $92.10 \%$ di banding dengan coral life yang hanya mencapai $29.70 \%$. pada titik ini tidak begitu banyak kegiatan pariwisata, sehingga kematian karang kemungkinan di akibatkan oleh faktor alami. Kedalaman pada setiap setasiun yang relatif dangkal memungkinkan menjadi penyebab hewan karang yang mati akibat terpapar sinar matahari lansung. Menurut Mulyana (2006) kematian karang dapat diaakibatkan oleh pasang surut, apabila terjadi pasang surut yang sangat rendah sehingga terumbu karang muncul di atas permukaan air dan terjadi pada siang hari (matahari terik), atau pada saat hujan sehingga air hujan lansung mengenai terumbu karang.

Secara keseluruhan fluktuasi penutupan coral life pada stasiun 1-3 (titik1-titik6) berkisar 2.30-29\% hal ini mengindikasikan bahwa kategori terumbu karang di kawasan Tanjung Gelam dalam kategori rusak buruk sampai rusak sedang, 0-24,9 merupakan kategori rusak buruk dan 25-49,9 merupakan kategori rusak sedang SK Meneg LH No.04/2001.Pada perairan Tanjung Gelam kondisi terumbu karang semakin buruk, penelitian Alfin dan Daniel (2016) pada kedalaman 3m diperairan Tanjung Gelam pada tahun 2013-2015 memperlihatkan terjadinya penurunan penutupan persentase terumbu karang yaitu pada tahun 2013 dengan nilai (66,8\%), 2014 dengan nilai $(55,6 \%)$, dan 2015 dengan nilai $(38,1 \%)$, terjadi penurunan dari kaegori baik menjadi kategori sedang.

\section{Potensi Perubahan Tutupan Terumbu Karang oleh Aktivitas Pariwisata}

Hasil pengolahan citra Landsat 8 menggunakan algoritma Lyzenga didapatkan pembagian objek sebanyak 6 kelas yaitu karang hidup, karang mati, pecahan karang, lamun, pasir dan laut. Daerah daratan tidak ikut terklasifikasi karena sebelumnya dilakukan masking untuk memisahkan daratan dan perairan. Data yang digunakan pada pengolahan citra ini mewakili data 3 tahun terakhir yaitu 2015,2016 dan 2017, gambaran perubahan dapat dilihat pada Tabel.8

Pada Tabel.8 perubahan luasan habitat menunjukan bahwa daerah yang luasannya berkurang tidaklah menghilang namun tergantikan oleh luasan habitat lain begitupun sebaliknya. Pada kisaran tahun 2015-20117 habitat yang mengalami fluktuasi yang cukup signifikan yaitu karang hidup dan pasir, sedangkan yang mengalami penurunan yaitu karang hidup, dan yang mengalami peningkatan yaitu karang mati dan lamun. Kemungkinan yang dapat terjadi karang hidup mengalami kematian sehingga pada tahun berikutnya terjadi kenaikan pada tutupan karang mati, hal ini juga dapat dikarenakan karang hidup yang patah akibat faktor alami ataupun manusia. Ekosisitem terumbu karang sangat rentan terhadap gangguan manusia dan lingkungan sehingga mudah mengalami kerusakan (Munasik,2009).

Faktor lingkungan yang sangat mempengaruhi penurunan luasan karang pada tahun 2015-2016 yang menyebabkan hilangnya 12.24 Ha karang hidup diduga yaitu perubahan musim pada tahun 2015 - 2016 yang sangat buruk. Penurunan tutupan karang di TN Karimunjawa disebabkan oleh beberapa faktor, diantaranya adalah pemutihan karang dan aktivitas wisata yang tidak ramah lingkungan. Pemutihan karang di Karimunjawa, terjadi pada tahun 2015 - 2016. National Oceanic and Atmospheric Administration (NOAA) menjelaskan bahwa pada akhir tahun 2015 hingga pertengahan 2016 terjadi peristiwa El Nino yang menyebabkan naiknya suhu permukaan laut yang berpusat di Samudera Pasifik, sehingga suhu perairan di Indonesa menjadi lebih hangat. Halini mengakibatkan memutihnya karang padasebagian besar lokasi pengamatan TN Karimunjawa (Pardede et al., 2016). Kejadian pemutihan karang kali ini telah berhasil dipantau dengan baik oleh Tim WCS-IP. Secara umum pemutihan karang pada tahun 2015-2016 mengalami 27\% karang memutih, 49\% pucat dan 12\% mati (KLH, 2017).Pada tahun 2016-2017 terjadi peningkatan luasan terumbu karang sebesar 8.01 ha hal tersebut dapat terjadi karena. Secara teoritis karang yang mati dapat mengalami pemulihan apabila kondisi lingkungan tetap baik.

Dalam kurun waktu 12 tahun, mulai dari tahun 2005 hingga tahun 2016, kondisi tutupan karang keras di Karimunjawa mengalami fluktuasi. Pada rentang 2006 hingga 2012, persentase tutupan karang keras di TN Karimunjawa mengalami kenaikan yang signifikan. Sedangkan pada tahun 2013 dan 2016, secara berturut- turut persentase karang keras di TN Karimunjawa mengalami penurunan (Pardede et al., 2016).

Faktor lain yang mempengaruhi perubahan luasan habitat yaitu kegiatan pariwisata dikarenakan kawasan Tanjung Gelam masuk pada zona pemanfaatan wisata bahari. Tercatat dari tahun 2014,2015 dan 2016 terus meningkat yaitu (79,123 orang), (92,115 orang) dan (118,301 orang) (BPS,2014; BPS,2015; BPS,2016).berikut adalah diagram kenaikan jumlah wisatawan di pulau karimunjawa :

Berdasar hasil survei, kerusakan yang ditimbulkan oleh adanya aktivitas wisata di Karimunjawa dinyatakan oleh WCS tahun 2010 (Kartawijaya et al., 2011) sekitar rata-rata 10\% terumbu karang mengalami kerusakan berupa patah dan beberapa bagian lain meningkatkan pertumbuhan alga serta hilangnya jaringan pada karang. Terdapat bukti adanya hubungan antara persen tutupan karang dengan pemanfaatan suatu lokasi, lokasi dengan pemanfaatan tinggi cenderung memiliki tutupan karang yang rendah (Juhasz et al., 2010). Terumbu karang sangat rentan terhadap aktivitas manusia, dapat berakibat menurunnya kemampuan regenerasi bahkan kematian seluruh koloni (Hall, 2001).

\footnotetext{
${ }^{\odot}$ Copyright by Management of Aquatic Resources (MAQUARES)
} 
Perubahan tutupan habitat karang hidup secara keseluruhan mengalami penurunan 4.22 Ha , pada karang mati mengalami penurunan setiap tahunya secara keseluruhan terjadi penurunan $8.25 \mathrm{Ha}$, sedangkan pada pecahan karang mengalami kenaikan pada setiap tahunya, secara keseluruhan terjadi kenaikan 16.02 Ha. Penurunan tutupan karang hidup dan karang mati diduga tergantikan oleh tutupan pecahan karang yang terus naik akibat faktor alami dan faktor jumlah wisatawan yang terus mengalami peningkatan. Tingginya tekanan terhadap terumbu karang berpengaruh secara signifikan terhadap kerusakan ekosistem terumbu karang (Wirada, 2012 dalam Sulisyati, 2014). Dari hasil pengamatan juga di temukan beberapa prilaku yang berpotensi merusak (kontak langsung) yang dilakukan oleh wisatwan, diantaranya yaitu fins kick, sit, stand,kneel, siltting, hand tauch, dan body brush dimana prilaku tersebut mengakibatkan dampak langsung terhadap terubu karang berupa goresan pada terumbu karang, patahan dan penutupan pada polip yang di sebabkan oleh sedimen yang terangkat.

Berdasarkan hasil penelitian didapatkan pada kawasan Tanjung Gelam didapatkan tingkat sensitifitas berada pada kisaran 2.14 yang masuk pada kategori rendah (lihat tabel.6) hal tersebut dikarenakan pada kawasan Tanjung Gelam mengalami penurunan tutpan terumbukarang pada tiga tahun terahir pada daerah perairan dangkal dengan kedalaman 3m, Alfi (2016) menyebutkan pada perairan Tanjung Gelam kedalaman $3 \mathrm{~m}$ terjadinya penurunan dari 2013-2015 yaitu 66.8\% menjadi 38,1\% yaitu dari kondisi sedang menjadi buruk.hal tersebut yang mengakibatkan penurunan pada parameter sensitifitas pada perairan Tanjung Gelam. Adapun hubungan perkembangan wisata dengan kerusakan terumbu karang terdapat keterkaitan hal ini dapat dilihat dari hasil uji regresi linier yang menunjukkan kategori berkaitan sangat kuat dengan nilai 93,5\% namun tingkat signifikasinya tergolong rendah dikarenakan jumlah data yang terbatas. Jika kerusakan ini dibiarkan terus-menerus bukan tidak mungkin pariwisata yang dikembangkan menjadi salah dalam pengelolaan dan akan menjadi salah satu penyebab kerusakan ekologi (Fandeli et al., 2009).

\section{KESIMPULAN}

Kesimpulan yang didapatkan dari hasil penelitian skripsi ini adalah:

1. Perkembangan wisata di Karimunjawa setiap tahunya yang mengalami kenaikan jumlah wisatawan dari tahun 2014 - 2016 mencapai 79.123 - 118.301 atau berkisar 39.178 orang, dan pembangunan fasilitas serta sarana prasarana yang semakin maju berpengaruh tehadap kondisi ekosisitem terumbu karang di kawasan tersebut yang mengalami penurunan dengan kondisi tutpan karang hidup pada kriteria rusak buruk dengan nilai rata rata 10,28. Keterkaitan pariwisata dengan kerusakan terumbu karang dapat dilihat dari hasil uji regresi linier yang menunjukkan kategori berkaitan sangat kuat dengan nilai 93,5\%.

2. Tingkat sensitifitas ekosisitem terumbu karang di kawasan tanjung gelam berada pada kategori rendah dengan nilai 2,14 atau dapat dikatakan mempunyai kemampuan internal untuk menerima tekana pada kategori rendah.

3. Perubahan luasan tutupan terumbukarang di Tanjung Gelam berdasarkan pengolahan menggunakan transformasi lyzenga pada data citra satelit yaitu didapatkan perubahan luasan habitat terumbu karang yang berkurang sebesar 4,22 Ha dari tahun 2015-2017.

\section{UCAPAN TERIMAKASIH}

Ucapan terimakasih ditujukan kepada semua pihak yang telah membantu sehingga penulis dapat menyelesaikan artikel ini.

\section{DAFATAR PUSTAKA}

Alfi, S. dan Daniel, A. M. 2013. Perbandingan Kondisi Terumbu Karang Selama Tiga Tahun Terahir pada Perairan Taka Malang dan Tanjung Gelam Kepulauan Karimunjawa. Prosiding Seminar Nasional Tahunan ke-V Hasil-Hasil Penenlitian Perikanan dan Kelautan. Fakultas Perikanan dan Ilmu Kelautan. Universitas Diponegoro. Semarang.

[BPS] Kabupaten Jepara. 2014. Jepara Dalam Angka 2014, BPS Kabupaten Jepara, Provinsi Jawa Tengah. 2015. Jepara Dalam Angka 2015, BPS Kabupaten Jepara, Provinsi Jawa Tengah. 2015. Jepara Dalam Angka 2015, BPS Kabupaten Jepara, Provinsi Jawa Tengah

[BTNKJ] Balai Taman Nasional Karimunjawa. 2004. Penataan Zonasi Taman Nasional Karimunjawa Kabupaten Jepara Provinsi Jawa Tengah. Balai Taman Nasional Karimunjawa. Semarang, 56 p.

2012. Rehabilitasi Terumbu Karang di Taman Nasional Karimunjawa Tahun 2012. Kementrian Kehutanan, Dirjen Perlindungan Hutan dan Konservasi Alam. 24 p.

Dahuri, R. 2003. Keanekaragaman Hayati Laut. Aset Pembangunan Berkelanjutan Indonesia. Gramedia Pustaka Utama. Jakarta.

Damayanti, Reina. 2012. Pemetaan Terumbu Karang di Perairan Pulau Tabuhan Kab. Banyuwangi Menggunakan Citra Satelit Quickbird. Program Studi Ilmu Kelautan Trunojoyo. Madura. 
English, S. Wilkinson, C.R. and Baker, V.J. 1994. Survey Manual for Tropical Marine Resources. Australian Institute of Marine Science. Town-sville. 368p

Fandeli, C., M. Baiquni \& Wijaya. 2009. Pengembangan Ekowisata Bahari Pulau Kecil Perbatasan Berbasis Masyarakat di Pulau Weh Sabang. Yogyakarta: Pusat Studi Pariwisata UGM.

Hall, C. 2001. Trends in Ocean and Coastal Tourism:The End of The Last Frontier? Ocean \& Coast. Manag. 44:601-618. Doi : 10.1016/ S0964-5691(01)00071

Juhasz, A., E. Ho, E. Bender \& P. Fong. 2010. Does Use of Tropical Beaches by Tourist and Island Resident Result in Damage to Fringing Coral Reef A Case Study in Moorea French Polynesia. Mar. Poll. Bull. 60:2251-2256.

Kartawijaya, T., R. Prasetia. Ripanto \& Jamaludin. 2011. Pengembangan Ekowisata Berbasis Masyarakat di Taman Nasional Karimunjawa. Bogor. 22p: Wildlife Conservation Society - Indonesia Program.

Kementrian Lingkungan Hidup dan Kehutanan Direktorat Jendral Konservasi Sumberdaya Alam dan Ekosisitem Balai Taman Nasional Karimunjawa. 2017.Statistik Balai Taman Nasional Karimunjawa Tahun 2016. Semarang.

Lasagna, R., G. Gnone, M. Taruffi, C. Morri, C. N. Bianchi, V. Parravicini, and S. Lavorano. S. 2014. A New Synthetic Index to Evaluate Reef Coral Condition, Ecological Indicators, 40: 1-9.

Mulyana, Y. 2006. Pedoman Pelaksanaan Transplantasi Karang. Direktorat Jenderal Kelautan, Pesisir dan PulauPulau Kecil. Departemen Kelautan dan Perikanan. Jakarta.

Munasik, 2009. Konservasi terumbu Karang, Badan Penerbit Universitas Diponegoro Semarang 117 hal.

Nybakken, J. W. 1992. Biologi Laut Suatu Pendekatan Ekologis. PT. Gramedia. Jakarta.

Odum, E. P. 1979. Fundamental of Ecology. Third Edition, W.B. Saunders Company. Toronto Florida.

Pardede, S.Sukmaraharja, A. R. T. Fakhrizal, S. Efin, M. Azhar, M. dan Muhidin. 2016. Laporan Teknis: Monitoring Ekosisitem Terumbu Karang Taman Nasional Karimunjawa 2016. Wildlife Conservation Society. Bogor.

Suhery, N. Ario, D. Dan Hefni, E. 2017. Indeks Kerentanan Ekosisitem Terumbu Karang Terhadap Tumpahan Minyak:Kasus Pulau Pramuka dan Pulau Belanda di Kepulauan Seribu. Jurnal Ilmu dan Teknologi Kelautan Tropis. Vol. 9 (1) : 67-90.

Sulisyati, R. Erny, P. Lies, R.WF. dan Chafid, F. 2014. Karakteristik Terumbu Karang di Zona Pemanfaatan Wisata Taman Nasional Karimunjawa. Ilmu kelautan. Vol. 19(3): 139-148.

Supriharyono. 2017. Konservasi Ekosistem Sumberdaya Hayati di Wilayah Pesisir dan Laut Tropis (edisi 3). Pustaka Belajar. Yogyakarta.

Susana, T. 2005. Kualitas Zat Hara Perairan Teluk Lada, Banten. Oseanologi dan Limnologi di Indonesia : 59-67.

[UNEP] United Nation Environment Protection, 1993. Penagamatan Terumbu karang dalam perubahan. Ilmu Kelautan. Australia.

Webler, T. and K. Jakubowski. 2016. Mitigating Damaging Behaviors of Snorklers to Coral Reefs in Puerto Rico Though a Pre-Trip Media-Based Intervention. Biological Coservation, 197:223-228. 